\title{
Study on the Trial-mix and Basic Properties of Desert Sand Steel-PVA Fiber High Performance Concrete
}

\author{
Quanwei LI, Jialing CHE*, Caixia MA, Lijun LIU \\ School of Civil Engineering and Hydraulic Engineering \\ Ningxia University \\ Yinchuan, China \\ e-mail: *che_jialing@126.com
}

\begin{abstract}
A kind of desert sand steel-PVA fiber high performance concrete is researched. The high performance concrete is composed of water, cement, fly ash and sand. Desert sand instead of part of the river sand, the replacement rate of $30 \%$; fly ash instead of part of the cement, the replacement rate of $15 \%$. The water-binder ratio is 0.19 . The content of the steel fiber is $\mathbf{1 . 2 \%}$ of the volume of the concrete, and the PVA fiber content is $0.8 \%$ of the volume of the concrete, based on the total volume of water, cement, fly ash and sand. The effect of desert sand on the properties of the specimens is obtained by comparing the properties of the specimens with desert sand and the properties of the specimens without sand. The desert sand replacement rate of $30 \%$ can increase the compressive strength and the splitting tensile strength, accompanied by a small degree of loss of bending strength. The desert sand steel-PVA fiber high performance concrete presented by this experiment does not contain coarse aggregate, and the properties meet design requirements of the concrete structure. This high performance concrete has the advantages of light weight, environmental protection, and good ductility.
\end{abstract}

Keywords-desert sand; high performance concrete; mechanical properties; PVA fiber; steel fiber

\section{INTRODUCTION}

The current world is at the peak of urban infrastructure development, for large-scale bridge engineering, railway engineering, municipal engineering, high-performance concrete is widely used, compared to ordinary concrete, high performance concrete needs the larger amount of cementing materials, the production cost is higher. However, with increases of the compressive strength of ordinary concrete, its tensile strength and shear strength is relatively low, ductility is relatively poor, thereby reducing the seismic performance of concrete structures. The natural sand used in traditional concrete, which is the formation and accumulation of rock debris in natural waters such as rivers and lakes. In recent years, the amount of concrete has been increasing and the natural sand resources have been basically dried up. For the desert and sandy areas, desert sand resources are very rich, but the transportation costs are high, which increase the construction costs. Many scholars have studied the engineering application of desert sand ${ }^{[1-8]}$.

In recent years, PVA fiber concrete has developed rapidly and is widely used in large-scale actual engineering projects. PVA fiber has the advantages of high strength, high elastic modulus, good fire resistance, wearable, anti-acid and anti-alkali. Cement, gypsum and other substrates have a good combination with it. And it is no pollution, non-toxic, harmless green building materials. However, the cost of PVA fiber is high, and the enhancement of matrix strength is not obvious to limit the application of PVA fiber in practical engineering. Strength of Steel fiber is high, the price of it is relatively low, the strengthening of the matrix strength and toughening is significant, but the corrosion resistance, durability is poor. If the local materials could be used, with the rational use of cheap local resources, the maximum and efficient use of industrial waste, the light environmental protection, high strength, high ductility concrete can be prepared. It is of great significance for reducing local construction costs, protecting the local environment and developing and utilizing local natural Resources rationally.

The purpose of this paper is to provide a kind of desert sand steel-PVA fiber high performance concrete and its preparation method for the shortcomings of the existing technology. With the exact mixing proportion, the desert sand is used instead of the part of river sand, local materials could be used, and desert resources could be made full use of.

\section{EXPERIMENT DESIGN}

\section{A. Experimental Material}

P.O.42.5 ordinary portland cement, class I fly ash of Ningxia Lingwu Thermal Power Plant. Add water reduction rate of $30 \%$ polycarboxylate high performance water reducing agent, water reducing agent added amount is $0.3 \%$ of the total mass of water, cement, fly ash and river sand. PVA fiber is high strength and high modulus polyvinyl alcohol fiber, the diameter is $0.040 \mathrm{~mm}$, length is $12 \mathrm{~mm}$, density is $1300 \mathrm{~kg} / \mathrm{m}^{3}$, strength is $1600 \mathrm{MPa}$, Young's modulus $\geq 380 \mathrm{GPa}$. Washed river sand, its diameter Dmax = $1.18 \mathrm{~mm}$, average diameter of desert sand is $0.238 \mathrm{~mm}$.

\section{B. Mix Proportion of Experiment}

The mix proportion design of the experiment is shown in Table I . No. 1 is with no desert sand, the replacement rates of the others are $10 \%, 20,30 \%$ and $40 \%$.

The amount of material put into the mixer is shown in Table II. 
TABLE I. MIX PROPORTION DESIGN

\begin{tabular}{|c|c|c|c|c|c|}
\hline $\begin{array}{l}\text { No. of Factors } \\
\text { Specimens }\end{array}$ & $\begin{array}{c}\text { Water-binder } \\
\text { Ratio }\end{array}$ & $\begin{array}{c}\text { Fly ash Replacement } \\
\text { Rate/\% }\end{array}$ & $\begin{array}{c}\text { Desert Sand Replacement } \\
\text { Rate/\% }\end{array}$ & $\begin{array}{c}\text { Proportion of PVA } \\
\text { Fiber/\% }\end{array}$ & $\begin{array}{c}\text { Proportion of Steel } \\
\text { Fiber/\% }\end{array}$ \\
\hline 1 & 0.19 & 15 & 0 & 0.8 & \\
\hline 2 & 0.19 & 15 & 10 & 0.8 & \\
\hline 3 & 0.19 & 15 & 20 & 0.8 & 1.2 \\
\hline 4 & 0.19 & 15 & 30 & 0.8 & \\
\hline 5 & 0.19 & 15 & 40 & 1.2 & \\
\hline
\end{tabular}

TABLE II. THE AMOUNT OF MATERIAL PUt INTO THE MIXER

\begin{tabular}{|c|c|c|c|c|c|c|c|}
\hline $\begin{array}{l}\text { No. of } \\
\text { specimens }\end{array}$ & $\begin{array}{c}\text { Water } \\
/ \mathbf{g}\end{array}$ & $\begin{array}{c}\text { Cement } \\
/ \mathbf{g}\end{array}$ & $\begin{array}{c}\text { Fly ash } \\
/ \mathbf{g}\end{array}$ & $\begin{array}{c}\text { River sand } \\
/ \mathbf{g}\end{array}$ & $\begin{array}{c}\text { Desert sand } \\
/ \mathbf{g}\end{array}$ & $\begin{array}{c}\text { PVA fiber } \\
/ \mathbf{g}\end{array}$ & $\begin{array}{c}\text { Steel fiber } \\
/ \mathbf{g}\end{array}$ \\
\hline 1 & 3149.6 & 14090.3 & 2486.5 & 5967.6 & 0 & 140.9 & 1268.4 \\
\hline 2 & 3149.6 & 14090.3 & 2486.5 & 5370.8 & 596.8 & 140.9 & 1268.4 \\
\hline 3 & 3149.6 & 14090.3 & 2486.5 & 4774.0 & 1193.5 & 140.9 & 1268.4 \\
\hline 4 & 3149.6 & 14090.3 & 2486.5 & 4177.4 & 1790.3 & 140.9 & 1268.4 \\
\hline 5 & 3149.6 & 14090.3 & 2486.5 & 3580.6 & 2387.0 & 140.9 & 1268.4 \\
\hline
\end{tabular}

TABLE III. TEST RESULTS

\begin{tabular}{|c|c|c|c|c|c|c|}
\hline $\begin{array}{l}\text { No. of Properties } \\
\text { specimens }\end{array}$ & $\begin{array}{c}\text { 7d compressive } \\
\text { strength } \\
\text { /MPa }\end{array}$ & $\begin{array}{c}\text { 7d splitting tensile } \\
\text { strength } \\
\text { /MPa }\end{array}$ & $\begin{array}{c}\text { 7d flexural } \\
\text { strength } \\
\text { /MPa }\end{array}$ & $\begin{array}{c}\text { 28d compressive } \\
\text { strength } \\
\text { /MPa }\end{array}$ & $\begin{array}{c}\text { 28d splitting } \\
\text { tensile strength } \\
\text { /MPa }\end{array}$ & $\begin{array}{c}\text { 28d } \\
\text { flexural strength } \\
\text { /MPa }\end{array}$ \\
\hline 1 & 71.03 & 22.58 & 18.75 & 89.67 & 28.69 & 22.57 \\
\hline 2 & 72.61 & 24.76 & 18.30 & 90.93 & 30.10 & \\
\hline 3 & 74.08 & 26.59 & 17.85 & 91.84 & 31.32 & 22.28 \\
\hline 4 & 75.54 & 28.30 & 17.49 & 92.76 & 32.45 & 22.04 \\
\hline 5 & 74.32 & 26.90 & 16.72 & 91.97 & 31.27 & 21.91 \\
\hline
\end{tabular}

\section{Experimental Method}

According to the mix proportion, first mix river sand and desert sand for $1 \mathrm{~min}$, then mix cement, fly ash into the mixer for $1 \mathrm{~min}$; according to the proportion, weigh steel fiber, and add steel fiber stirring for $1 \mathrm{~min}$; weigh waterreducing agent and water, put the water-reducing agent into the water so that water-reducing agent can fully dispersed, then mix for 2 minutes; weighed PVA fiber and add, with 2 minutes mixing, the desert sand steel-PVA fiber high performance concrete is prepared. The PVA fibers must be uniformly dispersed in the material to exert the toughness of the PVA fibers. During the mixing process, the PVA fibers are processed to flocculent shape, and then slowly added them in the mixer, so that the PVA fibers are uniformly dispersed in the material, to increase the ductility of PVA fiber concrete. After the end of the mixing, pouring test pieces and vibrating to make them dense. Demould After 24 hours, put test pieces under the standard conditions for $7 \mathrm{~d}$ and $28 \mathrm{~d}$ curing. After the completion of the maintenance of the specimens, to dry and perform the mechanical properties test.

Six pieces of test pieces with the size of $70.7 \mathrm{~mm} \times 70.7$ $\mathrm{mm} \times 70.7 \mathrm{~mm}$ are prepared and tested for compressive property. Six pieces of test pieces with the size of $100 \mathrm{~mm} \times$ $100 \mathrm{~mm} \times 100 \mathrm{~mm}$ are prepared to measure the splitting tensile property. Six pieces of test pieces with the size of $40 \mathrm{~mm} \times 40 \mathrm{~mm} \times 40 \mathrm{~mm}$ are used to test the flexural performance. The compressive strength, splitting tensile strength and flexural strength of the concrete were tested according to GB / T50081-2002 "Standard Test Method for Normal Concrete Mechanical Properties" after 7 days and 28 days of curing.

\section{EXPERIMENTAL RESULT AND ANALYSIS}

$28 \mathrm{~d}$ compressive strength, $28 \mathrm{~d}$ splitting tensile strength and $28 \mathrm{~d}$ flexural strength test results are shown in Table III.

\section{A. Intuitive Analysis}

It can be seen from Table III that when the replacement rate of desert sand is $30 \%$ (No. 4), the compressive strength and splitting tensile strength of the specimens are the highest, and the flexural strength decreases with the increase of desert sand replacement rate. The histogram is plotted from the test results of No.1 and No.4 in Table III, as shown in Fig 1.

According to Figure 1, the replacement rate of desert sand increased from 0 to $30 \%, 7 \mathrm{~d}, 28 \mathrm{~d}$ compressive strength and $7 \mathrm{~d}, 28 \mathrm{~d}$ splitting tensile strength was improved, $7 \mathrm{~d}, 28 \mathrm{~d}$ flexural strength decreased slightly. Indicating that the use of appropriate desert sand instead of river sand, The compressive strength and splitting tensile strength has a significant promotion, accompanied by a small degree of loss of flexural strength. As the particle size of river sand is larger, and the particle size of desert sand is small, take the appropriate amount of desert sand instead of river sand can make the concrete filled evenly, and increase the strength of concrete. 


\section{B. Analysis on the Improvement of Concrete Properties by Desert Sand}

According to the test results of No.1 and No.4 in Table III, the improvement of concrete properties by desert sand (30\% replacement) can be calculated, as shown in Table IV .

It can be seen from Table IV that when the replacement rate of desert sand increased from 0 to $30 \%$, the $7 d$ compressive strength increase by $6.35 \%$, the $28 \mathrm{~d}$ compressive strength increase by $3.45 \%$; the $7 \mathrm{~d}$ splitting tensile strength increase by $25.33 \%, 28 \mathrm{~d}$ splitting tensile strength increase by $13.11 \%$; $7 \mathrm{~d}$ flexural strength decrease by $6.72 \%, 28 \mathrm{~d}$ flexural strength decrease by $2.92 \%$.

With the desert sand replacement rate of $30 \%$, the compressive strength can be enhanced, the splitting tensile strength is significantly enhanced, while the flexural strength is slightly reduced.

\section{Analysis on Tension-compression Ratio and Flexure- compress Ratio}

Tension-compression ratio and flexure-compress ratio of specimens (No.1 and No.4) is shown in Table V .

Known from the tension-compression ratio and flexurecompress ratio of Table $\mathrm{V}$ are as following: tensioncompression ratio in the range of 0.318 to 0.375 , the flexurecompress ratio between 0.232 and 0.264 . The flexurecompression ratio of high performance concrete in literature [9] is $0.095 \sim 0.142$, and the tension-compression ratio is $0.064 \sim 0.099$. The experimental results show that the properties of steel-PVA fiber concrete is significantly higher than that of high performance concrete with the same strength grade, which indicates that the tensile and flexural properties of desert sand steel-PVA fiber high performance concrete has been greatly improved, the brittleness has been reduced, it is conducive to improving the crack resistance of concrete and volume stability. From the parameter in Table $\mathrm{V}$, we can see that with the addition of desert sand (30\%), the tension-compression ratio of the specimen is obviously improved and the flexure-compress ratio is slightly lower.

\section{CONCLUSION}

(1) To take the appropriate amount of desert sand to replace the river sand, the concrete can be filled evenly inside to increase the strength of concrete.

(2) With the desert sand replacement rate of $30 \%$, the compressive strength can be increased, splitting tensile strength is significantly improved, accompanied by a small degree of loss of flexural strength.

(3) Analysis shows that the tensile and flexural properties of concrete with PVA fiber and steel fiber have been greatly improved, and the brittleness has been reduced, which is beneficial to improve the crack resistance and volume stability of concrete.

(4) With the addition of desert sand (30\%), tensioncompression ratio of the specimens is obviously improved and the flexure-compress ratio is slightly reduced.

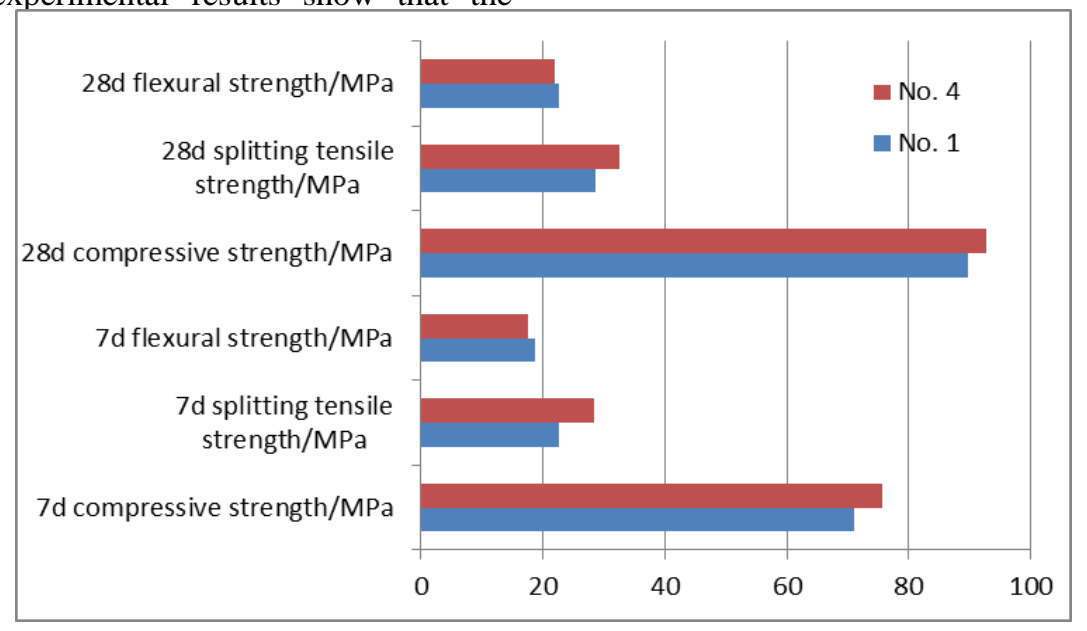

Figure 1. Histogram of test results.

TABLE IV. THE IMPROVEMENT OF CONCRETE PROPERTIES By DESERT SAND

\begin{tabular}{|c|c|c|c|c|c|c|}
\hline Properties & $\begin{array}{c}\text { 7d compressive } \\
\text { strength }\end{array}$ & $\begin{array}{c}\text { 7d splitting tensile } \\
\text { strength }\end{array}$ & $\begin{array}{c}\mathbf{7 d} \\
\text { flexural strength }\end{array}$ & $\begin{array}{c}\text { 28d compressive } \\
\text { strength }\end{array}$ & $\begin{array}{c}\text { 28d splitting tensile } \\
\text { strength }\end{array}$ & $\begin{array}{c}\mathbf{2 8 d} \\
\text { flexural strength }\end{array}$ \\
\hline Improvement & $6.35 \%$ & $3.45 \%$ & $25.33 \%$ & $13.11 \%$ & $-6.72 \%$ & $-2.92 \%$ \\
\hline
\end{tabular}

TABLE V. TENSION-COMPRESSION RATIO AND FLEXURE-COMPRESS RATIO

\begin{tabular}{|c|c|c|c|c|}
\hline $\begin{array}{l}\text { No. of } \\
\text { specimens }\end{array}$ & $\begin{array}{c}\text { 7d tension-compression } \\
\text { ratio }\end{array}$ & $\begin{array}{c}\text { 7d flexure-compress } \\
\text { ratio }\end{array}$ & $\begin{array}{c}\text { 28d tension-compression } \\
\text { ratio }\end{array}$ & $\begin{array}{c}\text { 28d } \\
\text { flexure-compress } \\
\text { ratio }\end{array}$ \\
\hline 1 & 0.318 & 0.264 & 0.320 & 0.252 \\
\hline 4 & 0.375 & 0.232 & 0.350 & 0.236 \\
\hline
\end{tabular}




\section{ACKNOWLEDGMENT}

This work was financially supported by the National Natural Science Foundation of China with No. 51408328, Ningxia Science and Technology Support Project with No. 2012ZYS264, Assessment and Reinforcement Method of Mosque Structure in Ningxia Area with No.NGY2015046. Ningxia College students' innovative entrepreneurial training program (201710749064, X201710749383).

\section{REFERENCES}

[1] Parra-Montesinos G J, "Peterfreund S W, Chao S H, "Highly damagetolerant beam-column joints through use of high-performance fiberreinforced cement composites," ACI Structural Journal, vol. 102, no. 3, pp.487- 495,2005.

[2] Li V C, Wang S, Wu C, "Tensile strain-hardening behavior of PVAECC,” ACI Material Jounal, vol. 98, no. 6, pp. 483-492, 2001

[3] Zhang Guoxue and Yang Jiansen,"Research on engineering characteristics of Tenggeli desert sand," Hlighway, vol. 8, pp. 131134, 2003 (in Chinese).
[4] Zhang Guoxue, Song Jianxia and Yang Jiansen,"Performance of mortar and concrete made with a fine aggregate of desert Sand," Building and Environment, vol. 41, no. 11, pp. 1478-1481, 2006.

[5] Mi Yongning, Sun Ronghua and Zhang Yuqing, "Concrete test of the super-fine sand preparation,"Concrete, vol. 12, pp. 56-59, 2011 (in Chinese).

[6] Wang $\mathrm{Na}$ and $\mathrm{Li}$ Bin, "Cooperating ratio design and research of Sahara desert sand high-strength concrete," Concrete, vol. 1, pp. 139146, 2014 (in Chinese).

[7] Yang Weiwu, Chen Yunlong and Ma Jurong,“ Influence of desert sand replacement ratio on the compressive strength of high strength concrete," Science Technology and Engineering, vol. 14, no. 19, pp. 306-309, 2014 (in Chinese).

[8] Fu Jie, Ma Jurong and Liu Haifeng,"Influence of fly ash dosage and desert sand replacement ratio on the mechanical properties of desert sand concrete," Journal of Guangxi University: Nat Sci Ed. vol. 4, no. 1, pp. 93-98, 2015 (in Chinese).

[9] Li Jun, Yin Jian, Zhou Shiqiong and Li Yijin,"Study on the strength of recycled aggregate concrete based on orthogonal experiment," China Civil Engineering Journal. vol. 39, no. 9, pp. 43-46, 2006 (in Chinese) 